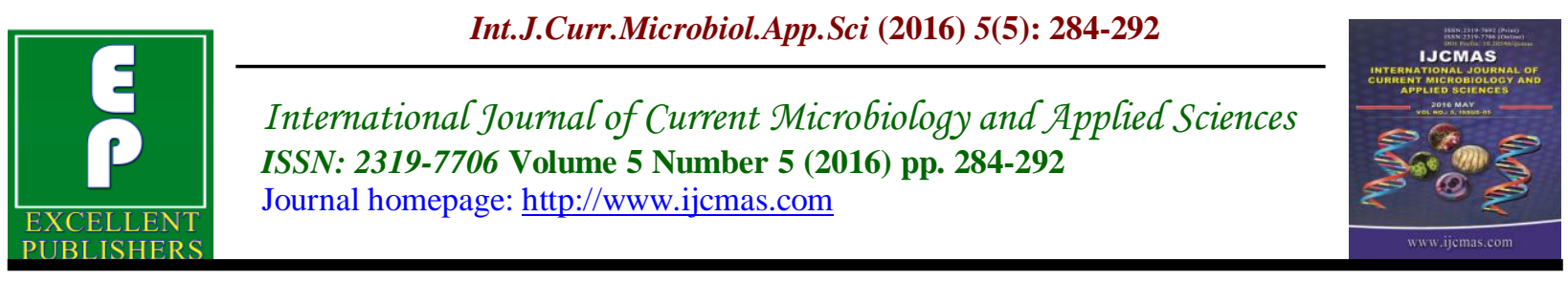

Original Research Article

http://dx.doi.org/10.20546/ijcmas.2016.505.031

\title{
Protein, Carbohydrate and Lipid Analysis of Ficus ficoides (Lamarck, 1822) from Vanjiure, Southeast Coast of India
}

\author{
K.G. Selvi* and P. Jeevanandham \\ PG and Research Department of Zoology, T.B.M.L.College, Porayar-609307, \\ TamilNadu, India \\ *Corresponding author
}

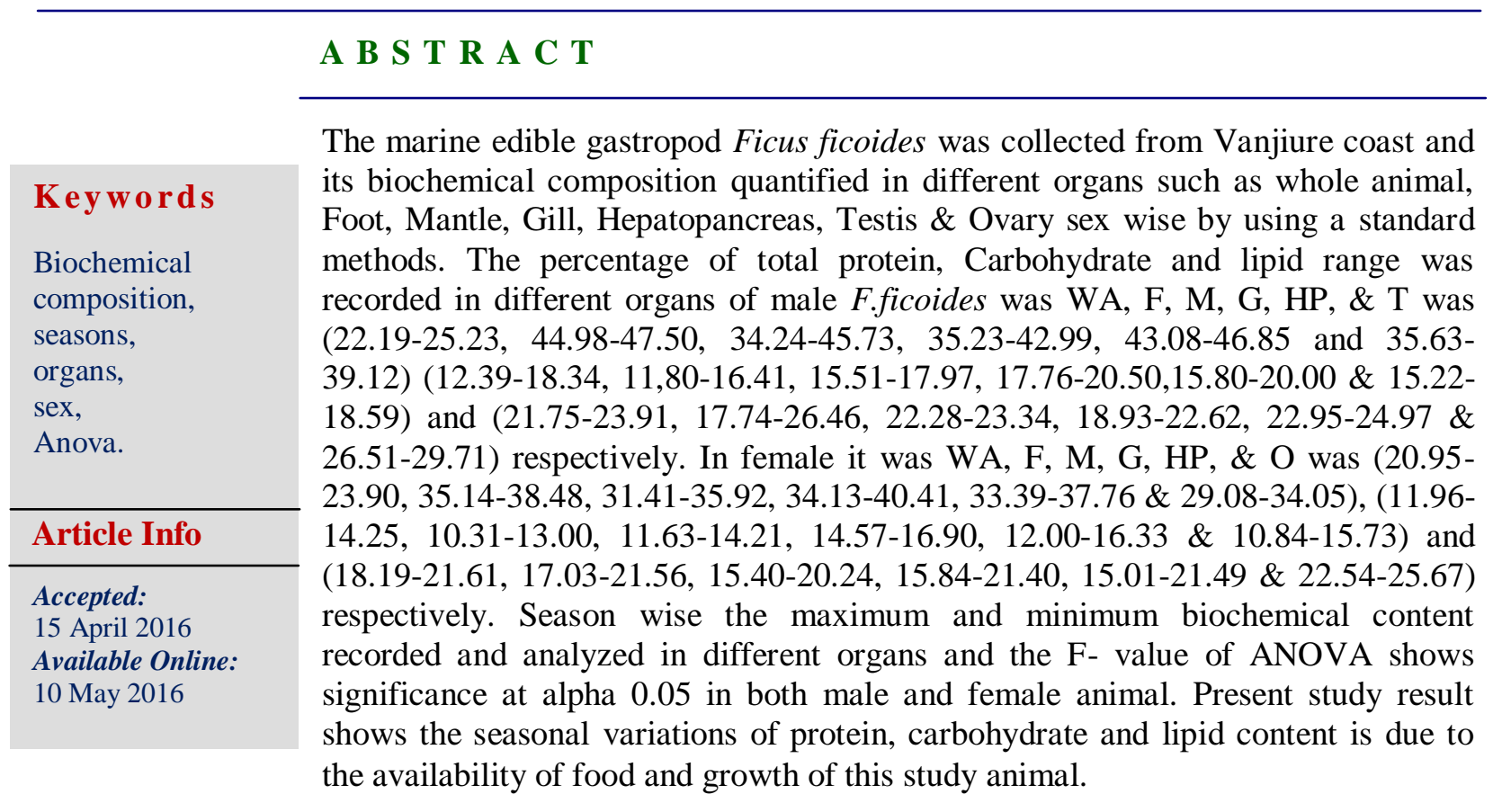

\section{Introduction}

Figsnails (Mesogastropods: Ficidae) are commonly called palchangu found in the warm seas of the world (Feinberg, 1979), Figsnails can be caught in sandy or muddy sub tidal habitats by bottom trawling (Lai, 1987).

In most of the Indian coasts it was seen that molluscs family so collected during fishing are regarded as fishery waste and are not used for edible purposes in India but rather used for poultry feedings, manure preparations and ornamental purposes. These molluscs, however, are a vital source of bioactive compounds of pharmaceutical importance (Morse et al., 1991).

The demand for protein rich food is increasing, especially in developing countries, stimulating the exploration of unexploited or non-traditional resources. In contrast to other countries the value of the edible gastropods as food has not been 
realized in India by majority of the people. The nutritional potential of the edible gastropod Ficus ficoides captured from Vanjiure coast has largely remained unexploited locally.

The knowledge on biochemical composition of any edible organisms is extremely important since the nutritive value is reflected in its biochemical contents (Nagabhushanam and Mane, 1978). Investigation on biochemical composition in different body parts will be more meaningful than the whole animal (Giese, 1969). Seasonal variations in the biochemical constituents of gastropod were reported by Stickle, 1973; Lambert and Dehnel, 1974; Suryanarayanan and Nair, 1976; Ansari. et al 1981; Maruthamuthu, 1988; Thivakaran, 1988; Stella, 1995 and Shanmugam, 2006.

Cyclical changes in biochemical composition of animal tissue are mainly studied to assess the nutritive status of an organism. This information may, however, be used in supplementing other studies like assessment of the course of the reproductive cycle. Marine bivalves indicated that seasonal cycle of energy storage and biochemical cycles are closely related to reproductive activity (Ruiz, et al., 1992).

Hence, the present study is planned to observe the protein, carbohydrate and lipid content in different body organs of $\mathrm{F}$. ficoides to understand the nutritive value of this species and to undertake future studies on the reproductive biology of this animal.

\section{Materials and Methods}

\section{Study Area and Period of Data Collection}

The marine gastropod Ficus ficoides (Fig:1) was collected from Vanjiure (Latitude: 100 51'52" N and Longitude: 0790 50' 56" E) coast. The study was conducted from
January 2014 to December 2014.Four seasons recognized at the study ares viz., post monsoon (January -March), summer (April-June), Pre monsoon (July-September) and Monsoon (October -December).The Northeast monsoon brings in heavy rainfall to the study area and is the deciding factor of the nature and extent of various seasons.

\section{Test Sample Preparation}

To observe the protein, carbohydrate and Lipid content in different organs such as the foot, mantle, gill, hepatopancreas, Testis, Ovary and whole animal body tissue of adult male and female animals were collected fortnightly from the field and were brought to the laboratory and kept in the tanks filled with sea water for 24 hours to ensure that the gut contents were released. These animals were dissected and the respective tissues were pooled up for biochemical analysis. The proximate compositions such as protein, carbohydrate and lipid of the experimental samples were determined by using standard methods and values were expressed as percentage of wet weight (mg/100mg) tissue.

\section{Estimation of Total Protein}

The Folin-Ciocalteu Phenol method of Lowry, et al., 1951 was adopted for the estimation of total protein in the tissue.

\section{Estimation of Total Carbohydrate}

The estimation of total carbohydrate content, the procedure of Dubois, et al., 1956 using phenol-sulfuric acid was followed.

\section{Estimation of Total Lipid}

The total lipid was estimated gravimetrically using chloroform-methanol method described by Folch, et al. (1956). 


\section{Statistical Analysis}

Statistical significance was evaluated by using ANOVA two factors with MS Office Excel Statistical Tool pack.

\section{Results and Discussion}

Biochemical contents quantified during the entire study period shown in Table 1-3. The fluctuation of protein, carbohydrate and lipid in the entire study period is due to the availability of food, growth and reproductive cycle.

Biochemical contents in male F.ficoides: The percentage of total protein range was recorded in different organs of adult species was whole animal body tissue (WA), Foot (F), Mantle (M), Gill (G), Hepatopancreas (HP), and Testis (T) was 22.19-25.23, $44.98-47.50, \quad 34.24-45.73, \quad 35.23-42.99$, 43.08-46.85 and 35.63-39.12 respectively. The carbohydrate content observed in the different organs viz., WA, F, M, G, HP \& T were 12.39-18.34, 11,80-16.41, 15.51-17.97, $17.76-20.50,15.80-20.00 \quad \& \quad 15.22-18.59$ respectively. The range of lipid content observed in the organs of WA, F, M, G, HP $\& \mathrm{~T}$ were $21.75-23.91,17.74-26.46,22.28$ $23.34,18.93-22.62,22.95-24.97 \& 26.51-$ 29.71 respectively

Biochemical contents in Female F.ficoides: The percentage of total protein range was recorded in different organs of adult species was whole animal body tissue (WA), Foot (F), Mantle (M), Gill (G), Hepatopancreas (HP), and Ovary (O) was 20.95-23.90, $35.14-38.48, \quad 31.41-35.92, \quad 34.13-40.41$, $33.39-37.76$ and $29.08-34.05$ respectively. The carbohydrate content showed in different organs viz., WA, F, M, G, HP \& O was 11.96-14.25, 10.31-13.00, 11.63-14.21, $14.57-16.90,12.00-16.33$ and 10.84-15.73 respectively. The lipid content ranges in the organs of WA, F, M, G, HP \& O was 18.19$21.61, \quad 17.03-21.56, \quad 15.40-20.24, \quad 15.84-$ $21.40, \quad 15.01-21.49 \quad \& \quad 22.54-25.67$ respectively.

\section{Season Wise Biochemical Content}

Season wise the maximum and minimum biochemical content recorded in different organs shows significant results Table 4-5. Seasonal changes of protein, carbohydrate and lipid content proves the growth and reproductive cycle of the study animal F.ficoides.

In the male F.ficoides the maximum protein content observed seasons and its respective organ was Postmonsoon- HP (46.85) and rest of the seasons the foot has protein between ranges of 44.98-47.50. The whole animal body tissue shows minimum protein in all the seasons with the ranges of 22.1925.23.In case of female F.ficoides the highest and lowest of protein recorded in the organ of gills \& WA body tissues in all the seasons were Postmonsoon (36.97 \& 23.90), summer(48.41 \& 22.64), Premonsoon (40.11 \& 22.12) \& Monsoon (35.37 \& 20.95) respectively.

Carbohydrate was quantified in both male and female animal's season wise. In both male and female maximum carbohydrate observed in the organ of gill in all the seasons were postmonsoon $(20.50,15.66)$, summer $(19.86,16.90)$, Premonsoon(19.06, 15.58) and Monsoon (17.76, 14.57). The minimum carbohydrate recorded in both male and female F.ficoides in the organ of foot in all the seasons were postmonsoon $(16.41,10.31)$, summer $(15.31,12.29)$, Premonsoon(13.60, 13.00) and Monsoon (11.80, 10.79)respectively.

In all the seasons the highest lipid content recorded in the organ of Testis \& Ovary 
were postmonsoon (26.51, 22.86), summer (28.32, 23.27), Premonsoon (29.71, 25.65) and Monsoon $(26.87,22.54)$.The minimum lipid observed in different organs of male animal were postmonsoon (mantle-23.24), Summer \& premonsoon (gills-22.62 \& 21.00) and monsoon (foot-17.74). In female animal minimum lipid observed data were postmonsoon \&monsoon (HP- 18.45 \& $15.01)$ and summer \& premonsoon was (mantle- $20.24 \& 17.72$ ) respectively.

In the present study the fluctuations in the biochemical constituent are largely attributable to the reproductive and feeding activities of the study animal. Further, the male F.ficoides have higher percentage of protein content than the female animal in all the seasons. Male and female F.ficoides has maximum protein in foot and gill organ shows more activity during the season of monsoon is a copulation period and minimum amount of protein recorded during the season of post monsoon period is the snail shows less activity after that spawning period. This present study was supported by Ranajit kumar khalua, et al., 2014 in his work he is reported that the maximum protein storage is due to the edible gastropod snail Bellama bengalensis having more activity during spawning period. This present work was supported by earlier studies of Soma Saha, 2004 in K.opima and similar, observations have been made by Palpandi et al. 2010 in C.melo and Thais mutabilis by Kamalkanth et al 2014.

Fig.1 Ficus ficoides

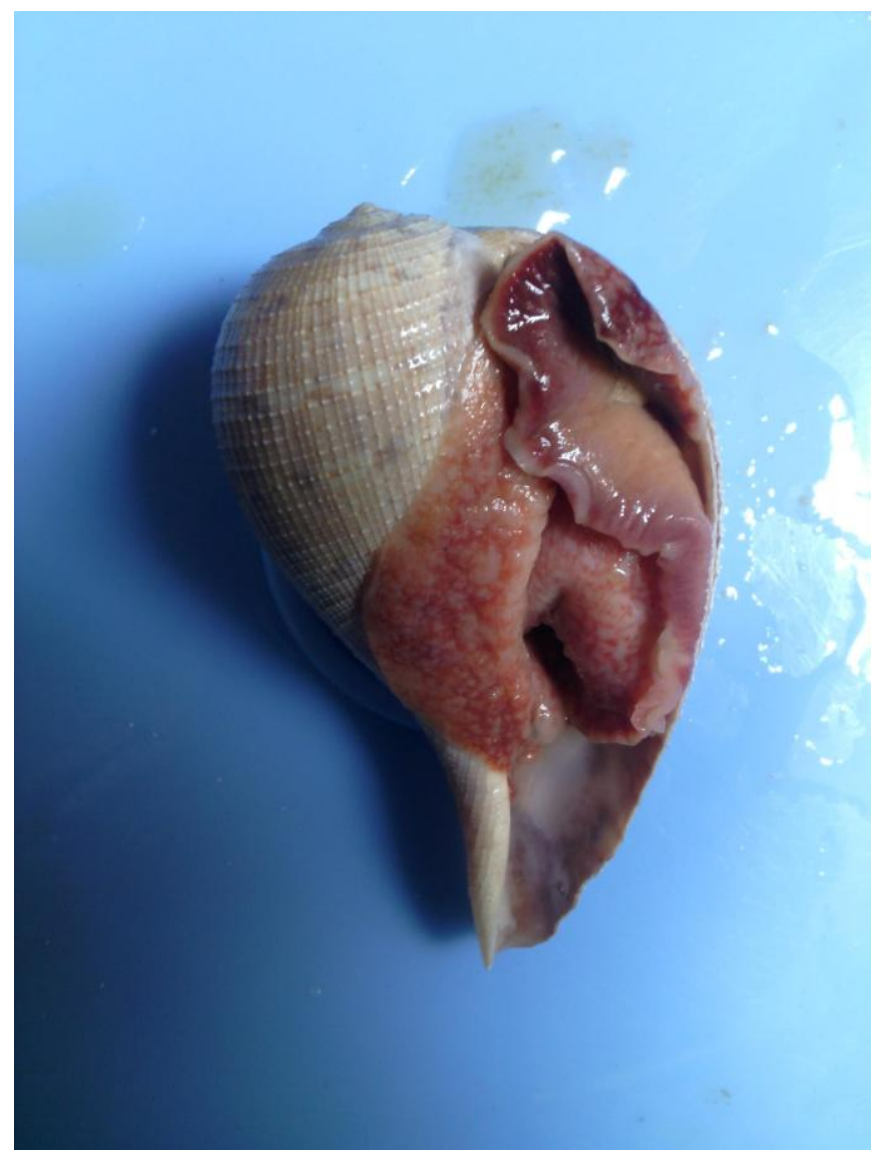


Int.J.Curr.Microbiol.App.Sci (2016) 5(5): 284-292

Table.1 Seasonal Changes of Protein Content in Different Organs of F. ficoides in Both Male and Female Animals

\begin{tabular}{|c|c|c|c|c|c|c|c|c|c|c|c|c|}
\hline \multirow{2}{*}{ 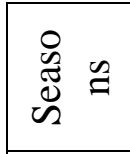 } & \multicolumn{2}{|c|}{$\begin{array}{l}\text { Whole Animal } \\
\text { body }\end{array}$} & \multicolumn{2}{|c|}{ Foot } & \multicolumn{2}{|c|}{ Mantle } & \multicolumn{2}{|c|}{ Gill } & \multicolumn{2}{|c|}{ Hepatopancreas } & \multicolumn{2}{|c|}{ Gonad } \\
\hline & $\hat{0}$ & 오․ & $\hat{0}$ & q & $\hat{0}$ & q & $\hat{0}$ & 오․ & $\hat{0}$ & q & $\hat{0}$ & q \\
\hline 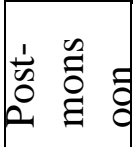 & $\begin{array}{l}25.23 \\
\pm \\
0.10\end{array}$ & $\begin{array}{l}23.90 \\
\pm \\
0.5\end{array}$ & $\begin{array}{l}46.58 \\
\pm \\
2.8\end{array}$ & $\begin{array}{l}35.14 \\
\pm \\
0.74\end{array}$ & $\begin{array}{l}45.73 \\
\pm \\
2.60\end{array}$ & $\begin{array}{l}31.41 \\
\pm \\
5.77\end{array}$ & $\begin{array}{l}42.99 \\
\pm \\
0.60\end{array}$ & $\begin{array}{l}36.97 \\
\pm \\
1.31\end{array}$ & $\begin{array}{l}46.85 \\
\pm \\
0.36\end{array}$ & $\begin{array}{l}33.39 \\
\pm \\
0.67\end{array}$ & $\begin{array}{l}39.12 \\
\pm \\
0.25\end{array}$ & $\begin{array}{l}29.08 \\
\pm \\
0.83\end{array}$ \\
\hline 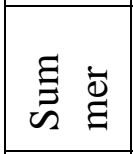 & $\begin{array}{l}24.70 \\
\pm \\
1.2\end{array}$ & $\begin{array}{l}22.64 \\
\pm \\
0.7\end{array}$ & $\begin{array}{l}47.50 \\
\pm \\
1.16\end{array}$ & $\begin{array}{l}38.48 \\
\pm \\
1.27\end{array}$ & $\begin{array}{l}42.60 \\
\pm \\
1.68\end{array}$ & $\begin{array}{l}34.79 \\
\pm \\
2.03\end{array}$ & $\begin{array}{l}42.10 \\
\pm \\
1.54\end{array}$ & $\begin{array}{l}40.41 \\
\pm \\
0.23\end{array}$ & $\begin{array}{l}44.28 \\
\pm \\
2.86\end{array}$ & $\begin{array}{l}37.76 \\
\pm \\
0.06\end{array}$ & $\begin{array}{l}36.86 \\
\pm \\
2.46\end{array}$ & $\begin{array}{l}30.52 \\
\pm \\
0.27\end{array}$ \\
\hline Dે & $\begin{array}{l}23.67 \\
\pm \\
0.5 \\
\end{array}$ & $\begin{array}{l}22.12 \\
\pm \\
0.4\end{array}$ & $\begin{array}{l}47.43 \\
\pm \\
0.8 \\
\end{array}$ & $\begin{array}{l}37.60 \\
\pm \\
1.28 \\
\end{array}$ & $\begin{array}{l}39.97 \\
\pm \\
3.72 \\
\end{array}$ & $\begin{array}{l}35.92 \\
\pm \\
2.29 \\
\end{array}$ & $\begin{array}{l}41.00 \\
\pm \\
1.78 \\
\end{array}$ & $\begin{array}{l}40.11 \\
\pm \\
3.32 \\
\end{array}$ & $\begin{array}{l}44.90 \\
\pm \\
2.79 \\
\end{array}$ & $\begin{array}{l}35.67 \\
\pm \\
1.31 \\
\end{array}$ & $\begin{array}{l}35.69 \\
\pm \\
5.04 \\
\end{array}$ & $\begin{array}{l}31.92 \\
\pm \\
2.64\end{array}$ \\
\hline$\stackrel{0}{\tilde{\Sigma}} \tilde{\delta}$ & $\begin{array}{l}22.19 \\
\pm \\
0.2\end{array}$ & $\begin{array}{l}20.95 \\
\pm \\
0.39 \\
\end{array}$ & $\begin{array}{l}44.98 \\
\pm \\
2.91\end{array}$ & $\begin{array}{l}35.37 \\
\pm \\
2.85\end{array}$ & $\begin{array}{l}34.24 \\
\pm \\
2.92 \\
\end{array}$ & $\begin{array}{l}34.03 \\
\pm \\
1.48\end{array}$ & $\begin{array}{l}35.23 \\
\pm \\
0.99 \\
\end{array}$ & $\begin{array}{l}34.13 \\
\pm \\
1.35 \\
\end{array}$ & $\begin{array}{l}43.08 \\
\pm \\
0.80\end{array}$ & $\begin{array}{l}35.23 \\
\pm \\
0.99\end{array}$ & $\begin{array}{l}35.63 \\
\pm \\
0.51 \\
\end{array}$ & $\begin{array}{l}34.05 \\
\pm \\
1.17 \\
\end{array}$ \\
\hline
\end{tabular}

ô-Male; + - Female

Table.2 Seasonal Changes of Carbohydrate Content in Different Organs of F. ficoides in Both Male and Female Animals

\begin{tabular}{|c|c|c|c|c|c|c|c|c|c|c|c|c|}
\hline \multirow{2}{*}{$\begin{array}{l}\mathscr{\Xi} \\
\tilde{0} \\
\tilde{\Xi} \\
\tilde{\Xi}\end{array}$} & \multicolumn{2}{|c|}{$\begin{array}{c}\text { Whole } \\
\text { Animal body }\end{array}$} & \multicolumn{2}{|c|}{ Foot } & \multicolumn{2}{|c|}{ Mantle } & \multicolumn{2}{|c|}{ Gill } & \multicolumn{2}{|c|}{ Hepatopancreas } & \multicolumn{2}{|c|}{ Gonad } \\
\hline & $\hat{0}$ & q & $\hat{0}$ & 오 & $\hat{0}$ & q & $\hat{0}$ & $q$ & $\hat{0}$ & $q$ & $\hat{0}$ & $q$ \\
\hline 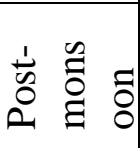 & $\begin{array}{l}18.34 \\
\pm \\
5.56\end{array}$ & $\begin{array}{l}13.28 \\
\pm \\
5.69\end{array}$ & $\begin{array}{l}16.41 \\
\pm \\
1.75\end{array}$ & $\begin{array}{l}10.31 \\
\pm \\
1.13\end{array}$ & $\begin{array}{l}17.97 \\
\pm \\
0.31\end{array}$ & $\begin{array}{l}14.21 \\
\pm \\
1.04\end{array}$ & $\begin{array}{l}20.50 \\
\pm \\
0.36\end{array}$ & $\begin{array}{l}15.66 \\
\pm \\
1.14\end{array}$ & $\begin{array}{l}20.10 \\
\pm \\
0.50\end{array}$ & $\begin{array}{l}16.33 \\
\pm \\
2.01\end{array}$ & $\begin{array}{l}18.59 \\
\pm \\
2.06\end{array}$ & $\begin{array}{l}15.73 \\
\pm \\
0.69\end{array}$ \\
\hline$\stackrel{\Xi}{\Xi} \bar{\Xi}$ & $\begin{array}{l}17.56 \\
\pm \\
2.76\end{array}$ & $\begin{array}{l}14.26 \\
\pm \\
1.33\end{array}$ & $\begin{array}{l}15.31 \\
\pm \\
1.75\end{array}$ & $\begin{array}{l}12.29 \\
\pm \\
1.13\end{array}$ & $\begin{array}{l}17.29 \\
\pm \\
0.88\end{array}$ & $\begin{array}{l}14.08 \\
\pm \\
1.49\end{array}$ & $\begin{array}{l}19.68 \\
\pm \\
0.90\end{array}$ & $\begin{array}{l}16.90 \\
\pm \\
0.56\end{array}$ & $\begin{array}{l}17.10 \\
\pm \\
5.49\end{array}$ & $\begin{array}{l}13.53 \\
\pm \\
1.57\end{array}$ & $\begin{array}{l}18.23 \\
\pm \\
2.91\end{array}$ & $\begin{array}{l}14.48 \\
\pm \\
1.06\end{array}$ \\
\hline ¿ & $\begin{array}{l}16.67 \\
\pm \\
2.76\end{array}$ & $\begin{array}{l}14.25 \\
\pm \\
1.33\end{array}$ & $\begin{array}{l}13.60 \\
\pm \\
1.75\end{array}$ & $\begin{array}{l}13.00 \\
\pm \\
1.13\end{array}$ & $\begin{array}{l}17.03 \\
\pm \\
0.52\end{array}$ & $\begin{array}{l}13.23 \\
\pm \\
0.31\end{array}$ & $\begin{array}{l}19.06 \\
\pm \\
0.70\end{array}$ & $\begin{array}{l}15.58 \\
\pm \\
1.51\end{array}$ & $\begin{array}{l}15.80 \\
\pm \\
2.71\end{array}$ & $\begin{array}{l}12.94 \\
\pm \\
0.64\end{array}$ & $\begin{array}{l}17.20 \\
\pm \\
2.14\end{array}$ & $\begin{array}{l}13.78 \\
\pm \\
0.89\end{array}$ \\
\hline$\stackrel{\tilde{0}}{\Sigma}^{\infty} \tilde{0}$ & $\begin{array}{l}12.39 \\
\pm \\
2.76\end{array}$ & $\begin{array}{l}11.96 \\
\pm \\
1.33\end{array}$ & $\begin{array}{l}11.80 \\
\pm \\
1.75\end{array}$ & $\begin{array}{l}10.79 \\
\pm \\
1.13\end{array}$ & $\begin{array}{l}15.51 \\
\pm \\
0.21\end{array}$ & $\begin{array}{l}11.63 \\
\pm \\
1.36\end{array}$ & $\begin{array}{l}17.76 \\
\pm \\
2.15\end{array}$ & $\begin{array}{l}14.57 \\
\pm \\
1.00\end{array}$ & $\begin{array}{l}17.39 \\
\pm \\
0.69\end{array}$ & $\begin{array}{l}12.00 \\
\pm \\
0.26\end{array}$ & $\begin{array}{l}15.22 \\
\pm \\
2.51\end{array}$ & $\begin{array}{l}10.84 \\
\pm \\
1.53\end{array}$ \\
\hline
\end{tabular}


Table.3 Seasonal Changes of Lipid Content in Different Organs of F. ficoides in Both Male and Female Animals

\begin{tabular}{|c|c|c|c|c|c|c|c|c|c|c|c|c|}
\hline \multirow{2}{*}{ 芯 } & \multicolumn{2}{|c|}{$\begin{array}{c}\text { Whole } \\
\text { Animal body }\end{array}$} & \multicolumn{2}{|c|}{ Foot } & \multicolumn{2}{|c|}{ Mantle } & \multicolumn{2}{|c|}{ Gill } & \multicolumn{2}{|c|}{ Hepatopancreas } & \multicolumn{2}{|c|}{ Gonad } \\
\hline & $0^{\lambda}$ & q & $\hat{0}$ & 9 & $\hat{0}$ & q & $\hat{0}$ & q & $\hat{0}$ & q & $\pi$ & q \\
\hline 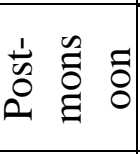 & $\begin{array}{l}23.91 \\
\pm \\
0.80\end{array}$ & $\begin{array}{l}21.14 \\
\pm \\
1.01\end{array}$ & $\begin{array}{l}26.46 \\
\pm \\
1.95\end{array}$ & $\begin{array}{l}0.77 \\
76 \\
\end{array}$ & $\begin{array}{l}23.34 \\
\pm \\
1.80\end{array}$ & $\begin{array}{l}18.27 \\
\pm \\
2.71\end{array}$ & $\begin{array}{l}21.50 \\
\pm \\
1.10\end{array}$ & $\begin{array}{l}18.92 \\
\pm \\
3.83 \\
\end{array}$ & $\begin{array}{l}24.21 \\
\pm \\
1.56\end{array}$ & $\begin{array}{l}8.45 \\
.72 \\
\end{array}$ & $\begin{array}{l}26.51 \\
\pm \\
0.95\end{array}$ & $\begin{array}{l}22.86 \\
\pm \\
1.78\end{array}$ \\
\hline 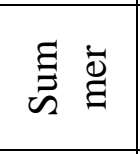 & $\begin{array}{l}23.66 \\
\pm \\
1.70\end{array}$ & $\begin{array}{l}21.61 \\
\pm \\
0.38\end{array}$ & $\begin{array}{l}24.48 \\
\pm \\
2.60\end{array}$ & $\begin{array}{l}21.56 \\
\pm \\
1.23\end{array}$ & $\begin{array}{l}23.30 \\
\pm \\
1.09\end{array}$ & $\begin{array}{l}20.24 \\
\pm \\
1.73\end{array}$ & $\begin{array}{l}22.62 \\
\pm \\
1.01\end{array}$ & $\begin{array}{l}21.40 \\
\pm \\
1.21 \\
\end{array}$ & $\begin{array}{l}24.97 \\
\pm \\
1.71 \\
\end{array}$ & 1.49 & $\begin{array}{l}8.32 \\
.41 \\
\end{array}$ & $\begin{array}{l}23.27 \\
\pm \\
0.95\end{array}$ \\
\hline 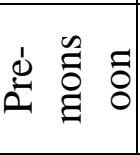 & $\begin{array}{l}23.55 \\
\pm \\
0.43\end{array}$ & $\begin{array}{l}21.00 \\
\pm \\
0.68\end{array}$ & $\begin{array}{l}22.45 \\
\pm \\
0.85\end{array}$ & $\begin{array}{l}20.40 \\
\pm \\
1.93\end{array}$ & $\begin{array}{l}22.65 \\
\pm \\
1.14\end{array}$ & $\begin{array}{l}17.72 \\
\pm \\
1.52\end{array}$ & $\begin{array}{l}21.00 \\
\pm \\
0.88\end{array}$ & $\begin{array}{l}19.70 \\
\pm \\
1.10\end{array}$ & $\begin{array}{l}22.95 \\
\pm \\
0.80\end{array}$ & $\begin{array}{l}19.95 \\
\pm \\
0.53\end{array}$ & $\begin{array}{l}29.71 \\
\pm \\
0.62\end{array}$ & $\begin{array}{l}25.67 \\
\pm \\
0.67\end{array}$ \\
\hline$\sum_{\Sigma}^{20} \tilde{\Xi}$ & $\begin{array}{l}21.75 \\
\pm \\
1.22\end{array}$ & $\begin{array}{l}18.19 \\
\pm \\
1.78\end{array}$ & $\begin{array}{l}17.74 \\
\pm \\
0.85\end{array}$ & $\begin{array}{l}17.03 \\
\pm \\
1.93\end{array}$ & $\begin{array}{l}22.28 \\
\pm \\
1.14\end{array}$ & $\begin{array}{l}15.40 \\
\pm \\
1.52\end{array}$ & $\begin{array}{l}18.93 \\
\pm \\
0.53\end{array}$ & $\begin{array}{l}15.84 \\
\pm \\
1.96\end{array}$ & $\begin{array}{l}23.41 \\
\pm \\
1.96\end{array}$ & $\begin{array}{l}15.01 \\
\pm \\
1.69\end{array}$ & $\begin{array}{l}26.87 \\
\pm \\
1.33\end{array}$ & $\begin{array}{l}22.54 \\
\pm \\
2.03\end{array}$ \\
\hline
\end{tabular}

Table.4 Anova Analysis for between Seasons and Organs in Male F. ficoides

\begin{tabular}{|lcrrrr|}
\hline $\begin{array}{c}\text { Source of Variation } \\
\text { (Male) }\end{array}$ & $S S$ & $D f$ & $M S$ & $F$ & P-value \\
\hline \multicolumn{5}{c}{ Protein } \\
Between seasons & 86.51336 & 3 & 28.83779 & 9.371048 & 0.000982 \\
Between organs & 1308.362 & 5 & 261.6724 & 85.03234 & $1.83 \mathrm{E}-10$ \\
Error & 46.15992 & 15 & 3.077328 & & \\
& \multicolumn{5}{c}{ Carbohydrate } \\
Between seasons & 42.77636 & 3 & 14.25879 & 14.81754 & $9.34 \mathrm{E}-05$ \\
Between organs & 53.86225 & 5 & 10.77245 & 11.19458 & 0.000124 \\
Error & 14.43437 & 15 & 0.962291 & & \\
& & & & \\
Between seasons & 27.53379 & 3 & 9.177929 & 4.02927 & 0.027503 \\
Between organs & 104.6746 & 5 & 20.93492 & 9.190793 & 0.000365 \\
Error & 34.16721 & 15 & 2.277814 & & \\
\hline
\end{tabular}

Significance at $\mathrm{p}=0.05$ 
Table.5 Anova Analysis for between Seasons and Organs in Female $F$. ficoides

\begin{tabular}{|c|c|c|c|c|c|}
\hline $\begin{array}{c}\text { Source of Variation } \\
\text { (Female) }\end{array}$ & $S S$ & $D f$ & $M S$ & $F$ & P-value \\
\hline \multicolumn{6}{|c|}{ Protein } \\
\hline Between seasons & 25.96388 & 3 & 8.654626 & 2.757386 & 0.078768 \\
\hline Between organs & 638.5666 & 5 & 127.7133 & 40.6898 & $3.34 \mathrm{E}-08$ \\
\hline Error & 47.0806 & 15 & 3.138706 & & \\
\hline \multicolumn{6}{|c|}{ Carbohydrate } \\
\hline Between seasons & 21.36458 & 3 & 7.121528 & 6.218702 & 0.005884 \\
\hline Between organs & 33.82844 & 5 & 6.765688 & 5.907974 & 0.003271 \\
\hline Error & 17.17769 & 15 & 1.145179 & & \\
\hline \multicolumn{6}{|c|}{ Lipid } \\
\hline Between seasons & 61.03879 & 3 & 20.34626 & 19.8739 & $1.75 \mathrm{E}-05$ \\
\hline Between organs & 80.49049 & 5 & 16.0981 & 15.72436 & $1.68 \mathrm{E}-05$ \\
\hline Error & 15.35652 & 15 & 1.023768 & & \\
\hline
\end{tabular}

Significance at $\mathrm{p}=0.05$

Carbohydrate content was higher in the gills of both male and female $F$.ficoides in all the seasons followed by foot, mantle Hepatopancreas, gonad and whole animal body. Season wise changes in the carbohydrates content may be due to accumulation and utilization of carbohydrate at different stages of their life cycle like gametogenesis and spawning. Similar work was reported by Baskara 2001 in the foot tissue of Lambis lambis and in the C.melo by Palpandi et al., 2010.

In the present study the lipid content was higher than the carbohydrate and lower than that of the protein values. The highest lipid content recorded in all the seasons in the gonad of both male and female $F$.ficoides.

The lipid content higher in gonad was followed by foot, mantle, gill, HP and whole animal body tissue. The significance of the present study also confirms the fact that the high lipid level in the tissue is due to intensive feeding and maturation of the gonads.
This similar work is reported in other edible molluscs are Ananda Kumar et al., 1986 reported in the value of lipid to range from 15.0- 23.6 in Hemifusus pugilinus; Ramesh, et al., 1992 observed in Chicoreus ramosus, the lipid values assessed at 2 percent in foot muscle; Rajakumar, 1995 observed the lipid content in Rapana rapiformis ranged from 0.85-2.12 percent in male and 0.95-2.96 in female.

The spawning cycle and food supply are the main factors responsible for this seasonal variation of protein, carbohydrate and lipid content. The nutritional contents of adult F.ficoides are closely linked to the reproductive cycle and availability of natural food

\section{Acknowledgement}

Authors are thankful to the Principal, HOD, Associate \& Assistant professors of the Department of Zoology, T.B.M.L.College, Porayar for providing necessary facilities to execute this work. 


\section{References}

Ananda Kumar, S., Amutha Rani, G., Gladys Chandra Leela, A., Pragatheswaran, V. 1986. Biochemical studies on a little known marine gastropod Hemifusus pugilinus Born (Volemidae). J. Marine Biol. Assoc. India, 28: 1-2.

Anasri, A., Parulekar, A.H., Motondkar, S.G.D. 1981. Seasonal changes in meat weight and biochemical compositon in the black clam, Villorita cyprinoides (grey). Indian J. Marine Sci., 10: 12137.

Baskara, S.S. 2001. Studies on eco biology of the spider conch Lambis lambis (Linne, 1758) from the Mandapam waters, southeast coast of India. Ph.D thesis Annamalai University, 160.

Beukema, J.J. 1997. Caloric values of marine invertebrates with an emphasis on the soft parts of marine bivalves. Oceanography. Mar. Biol., 35: $387-$ 414.

Caers, M., Coutteau, P., Sorgeloo, P. 2000. Impact of starvation and of feedong algal and artificial diets on the lipid content and composition of juvenile Oysters (Crossostrea gigas) and Clams (T.philippinarum). Mar. Biol., 136: 891-899.

Dubois, M., Gilles, K.A., Hamilton, J.K., Rebers, P.A., Smith, F. 1956. Colorimetric method for determination of sugar and related substances. Anal. Chem., 28(3): 350-356.

Folch, J.M., Lees, G. H. 1956. Sloane Stanley: A simple method for the isolation and purification of total lipids from animal tissues. J. Biol. Chem., 226: 497-509.

Gabbott, P.A., Bayne, B.L. 1973. Biochemical effects of temperature and nutritive stress on Mytilus edulis.L. J.
Mar. Biol. Assoc. UK, 53: 269-286.

Galap, C., Leboulenger, F., Grillot, J.P. 1997. Seasonal variations in biochemical constituents during the reproductive cycle of the female dog cockle Glycymeris glycymeris. Mar. Biol., 129: 625-634.

Giese, A. C. 1969. A new approach to the biochemical composition of the molluscan body. Oceanography Mar. Biol. Ann. Rev., 7: 175-229.

Kamalkanth, S., Christy Ponni, A., Muniyan, M., Chandravathani, S. 2014. Biochemical composition of intertidal Muricid Gastropod Thais mutbbilis (Link) in Tranquebar, Nagapattinam District, Southeast coast of TamilNadu, India. Int. J. Modern Res. Rev., 2(1): 8-14.

Lai, K.Y. 1987. Marine gastropods of Taiwan (2), Taipei: Taiwan Museum, 116.

Lambert, P., Dehnelm, P.A. 1974. Seasonal variations in the biochemical composition during the reproductive cycle of intertidal gastropod Thai lamellose (Gmelin) (Gastropod: Prosobeanchia) Can. J. Zool., 52: 305318.

Lowry, O.H., Rosebrough, N.J., Farr, A.L., Randall, R.J. 1951. Protein measurement with the folin phenol reagent. J. Biol. Chem., 193: 265-273.

Maruthamuthu, S.1988. Studies on Littorina undulata

(Gray,1839)

(Mesogastropods: ittorinidae) from Tranquebar and Mandapam Waters, Southeast Coast of India. Ph.D.Thesis, Annamalai University, India, 106133.

Morse, A.N.C., Thompson, M.F., Sarajoni R., Nagabhushanam, R. 1991. Bioactive compounds from marine organisms with emphasis on the Indian Ocean. Marine Drugs, 16: 164167. 
Nagabhushanam, R., Mane, V.H. 1978. Seasonal variation in the biochemical composition of perna viridis at Ratnagiri on the west coast of India, Hydrobiologia, 57(3): 69-72.

Palpandi, C., Vairamani, S., Shanmugam, A. 2010. Proximate composition and fatty acid profile of different tissues of the marine neogastropod Cymbium melo (Solander, 1786). Indian J. Fish, 57(3): 35-39.

Rajakumar, T. 1995. Studies on Rapana rapiformis(Born)(Mollusca:Gastropoda :Muricidae: Rapaninae) from Parangipettai coastal water, India. Ph.D. Thesis, Annamalai University, 185.

Ramesh, M.X., Ayyakkannu, K. 1992. Nutritive value of Chicoreus ramosus: A status report. Phuket Mar. Biol. Cent. Spec., 10: 14.

Ranajit Kumar Khalua, Satyajit Tripathy, Bhagyasree Paul, Debabrata Bairy. 2014. Seasonal Variation of Carbohydrate, Protein and Lipid of Common Freshwater Edible Gastropod (Bellamya bengalensis) of Medinipur District, West Bengal. Res. J. Biol., 2: 49-52.

Ruiz, C., Abad, M., Sedano, F., Martin, O.G., Sanchez, J.L. 1992. Influence of seasonal environmental changes on the gamete production and biochemical composition of Crassostrea gigas (Thunberg) in suspended culture in El Grove, Galicia, Spain. J. Exp. Mar. Biol. Ecol., 155: 249-262.

Shanmugam, A., Bhuvaneswari, T.,
Arumugam, M., Nazeer, R.A., Sambasivam, S. 2006. Tissue chemistry of Babylonia spirata(Linnaeus). Indian J. Fish., 53(1): 33-39.

Soma Saha. 2004. Tissue chemistry of inflated clam Katelysia opima (Gmelin). M. Sc. thesis, Annamalai University, India, 25.

Spector, A.A., Yorek, M.A. 1985. Membrane lipid composition and cellular function. J. Lipid Res., 26: 1015-1035.

Stella, C. 1995. Studies on the taxonomy and ecobiology of Chicoreus sps. (Gastropoda:Family: Muricidae) Parangipettai, Southeast Coast of India (Lat 11030'N; Long 79035'E) Ph.D., Thesis, Annamalai University, India. $1-195$.

Stickle, W.B., Mrozek, J.P. 1973. Seasonal changes in the body component of the subtidal prosobranch Fusitrition oregonensis. Veliger, 16: 195-199.

Suryanarayanan, H., Nair, N.B. 1976. Seasonal variation in the biochemical constitutes of Cellona radiatta (Born). Indian J. Mar. Sci., 5: 126-128.

Thivakaran, G.A. 1988. Studies on Littorinids Littorina quadricentus (Philippi) and Nodilittorina pyramidalis (Ouoy and Gaimard, 1833) (gastropoda: Prosobranchia: Littorinidae) from the Tranquebar rocky shore (Southeast Coast of India) Ph.D., Thesis, Annamalai University, India, 179.

\section{How to cite this article:}

Selvi, K.G., and Jeevanandham, P. 2016. Protein, Carbohydrate and Lipid Analysis of Ficusficoides (lamarck, 1822) from Vanjiure, Southeastcoast of India. Int.J.Curr.Microbiol.App.Sci. 5(5): 284-292. doi: http://dx.doi.org/10.20546/ijcmas.2016.505.031 